\title{
Vulnerability of Eco-Hydrological Environment in the Yellow River Delta Wetland
}

\author{
Maosheng Gao ${ }^{\dagger \ddagger}$, Sen Liu ${ }^{\dagger \dagger}$, Guangming Zhao ${ }^{\dagger \star}$, Hongming Yuan ${ }^{\dagger \ddagger}$, Caibo Wei ${ }^{\dagger \dagger}$, \\ Yanhua $\mathrm{Wu}^{\dagger \dagger}$, and Jianhui Tang \\ Key Laboratory of Coastal Wetlands \\ China Geologic Survey \\ Qingdao 266071, China \\ ${ }^{\dagger}$ Exploration Institute of Geology \\ and Mineral Resources \\ "Qingdao Institute of Marine Geology \\ Qingdao 266071, China \\ Yantai Institute of Coastal Zone Research \\ Chinese Academy of Sciences \\ Yantai 264003, China \\ §The Environmental \\ Science and \\ Engineering Academy \\ Ocean University of China \\ Qingdao 266100, China
}

Weifang 261021, China

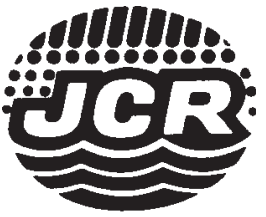

www.JCRonline.org

ABSTRACT

Gao, M.; Liu, S.; Zhao, G.; Yuan, H.; Wei, C.; Wu, Y., and Tang, J., 2014. Vulnerability of eco-hydrological environment in the Yellow River delta wetland. Journal of Coastal Research, 30(2), 344-350. Coconut Creek (Florida), ISSN 0749-0208.

We investigated the relationship between groundwater head and oceanic tidal fluctuations in the Yellow River Delta wetland through on-site hydrological monitoring. Shallow groundwater heads were obviously affected by oceanic tide along the coastal zone. The ranges of the wetland zone can be readily assessed by measuring fluctuation amplitudes or lags. The results show that the influence radius is approximately $12 \mathrm{~km}$ to $18 \mathrm{~km}$ (when the correlation coefficient is 0.7 to 0.8 ) under the joint actions of oceanic tide and shallow groundwater seepage flow in clayey silt coastal wetland. A cross-sectional sketch of the coastal wetland model is developed based on monitoring data of groundwater and oceanic tidal fluctuations to study the vulnerability of the eco-hydrological environment in the Yellow River Delta wetland. The coastal wetland consists of three zones (the groundwater seepage zone, the tidal-induced transitional zone, and the tidal zone) with distinctly different hydraulic properties. Analytical solutions are used to estimate the vulnerability of the ecohydrological environment in the wetland aquifer located in the NE part of the Yellow River Delta wetland, Shandong Province, China. Our results show that changes in the shallow groundwater quality of the wetland are significantly affected by natural factors, such as strong cutoff in the lower reaches, storm tides, and human engineering activities. The northern coastal wetland may be submerged without damp proof when the height of a storm tide reaches $2.4 \mathrm{~m}$. The depth of shallow groundwater and the salinity gradient are key factors that contribute to the vulnerability of the ecological environment. The vulnerability of the eco-hydrological environment is derived from the joint actions of groundwater dynamics, hydrochemistry, and tidal-induced processes under sedimentary stress and water pressure.

ADDITIONAL INDEX WORDS: Coastal wetland, groundwater head fluctuation, tidal fluctuation, correlation coefficient, vulnerability.

\section{INTRODUCTION}

The Yellow River delta is located in the NE of the Shandong Peninsula in China. The delta has formed eight overlaid distributary lobes since 1855 (Cheng, 1991; Xue, 1994). The developing lobes in the Yellow River delta are defined by the distribution range of distributary channels formed in 1976. These distributary channels are still active now because of human initiatives such as the water-sediment regulation scheme (WSRS) implemented by the Yellow River Conservancy Committee (YRCC). The Yellow River delta, spreading over an area of $4500 \mathrm{~km}^{2}$, has become the youngest and most vulnerable wetland coastal zone in the world (Pang, Jing, and Li, 2000).

Coastal wetlands are important transition zones between land and ocean with water depth no more than $6 \mathrm{~m}$. They are mainly composed of distributary channels, crevasse splays, natural levees, floodplains, and sedimentary depressions. Coastal wetlands provide an ideal place for reeds growth since

DOI: 10.2112 /JCOASTRES-D-13-00016.1 received 20 January 2013, accepted in revision 1 March 2013; corrected proofs received 16 April 2013.

Published Pre-print online 1 May 2013.

*Corresponding author: luicent@sina.com

(C) Coastal Education \& Research Foundation 2014 their clay sand or clay surface is permeable. During the wet season, rainwater can easily permeate deeply and irrigate the reeds. Since the 1980s, a number of changes (such as the Yellow River cutoff, storm tide, aggravated salinization, and coastal engineering activities) have altered the natural conditions of the Yellow River delta. As a result, the ecological functions of the wetland have been exhausted and reeds have degraded or disappeared. Since 2000, the Chinese government has continually enhanced the protection of the wetland ecological environment, including annual water-sediment regulation in the Yellow River. Therefore, the degraded wetland ecological system has been partially restored. However, numerous vulnerability problems still exist (Cao et al., 2007; Wang and Zhang, 1998).

Since the $1950 \mathrm{~s}$, a large number of analytical studies have been conducted on how groundwater responds to tidal fluctuation (Jacob, 1950; Jiao and Tang, 1999; Li et al., 2002, 2007; Nielsen et al., 1997; Sun, 1997; Townley, 1995; Trefry and Bekele, 2004). Most of these studies assumed that the aquifer is homogeneous. However, this assumption may be invalid because coastal aquifers consist of zones with different hydraulic properties. Such zonation may be caused by facies changes in stratigraphy and delta aggradation and/or distrib- 
utary channel swing. Trefry (1999) presented comprehensive solutions for a finite aquifer consisting of arbitrary numbers of adjacent homogeneous zones and subject to sinusoidal linear boundary conditions. Trefry indicated that the complexity of resulting expressions, even for simple composite aquifers, can distract attention from the underlying physics. Trefry and Bekele (2004) evaluated the suitability of various simple models of tidal propagation by using a set of groundwater head time series data collected along a transect in a sedimentary island aquifer near Perth, Western Australia. These researchers concluded that the model that involves composite heterogeneity coincides well with the observed spatial bias in the well responses (attenuations and lags), which cannot be modeled by a homogeneous aquifer theory. Winter et al. (1998) discussed correlativity of the river, wetland groundwater, landform, and climate. By studying wetland vegetation, water depth, and permeability, Cevza et al. (2008) presented wetland environmental conditions by modeling to control surface water and groundwater. Other researchers conducted numerical studies on saltwater intrusion in a coastal aquifer using a three-dimensional (3D) model (Feseker, 2007; Li et al., 2002; Oude Essink, 2001; Restrepo, Montoya, and Obevsekera, 1998). This model can be effectively used for hydrological restoration to reduce wetland surface water runoff and improve water quality (Gao and Swarzenski, 2011; Swarzenski et al., 2008).

\section{METHODS}

Monitoring data were obtained from three representative wells (a total of 10 observing wells) in the modern Yellow River delta for a Mass Land Resource Investigation Project (No. $1212010611402)$ from 2006 to 2009 . The ZK1 well $\left(37^{\circ} 45^{\prime} 26^{\prime \prime} \mathrm{N}\right.$, $\left.118^{\circ} 56^{\prime} 23^{\prime \prime} \mathrm{E}\right)$ is located in Estuary Town, south of the Yellow River; the ZK2 well ( $\left.37^{\circ} 53^{\prime} 49^{\prime \prime} \mathrm{N}, 118^{\circ} 40^{\prime} 51^{\prime \prime} \mathrm{E}\right)$ in Gudao Town, north of the river; and the ZK10 well (37 $\left.49^{\prime} 43^{\prime \prime} \mathrm{N}, 118^{\circ} 57^{\prime} 13^{\prime \prime} \mathrm{E}\right)$ east of the river. The monitoring sites are shown in Figure 1. Gao, Yuan, and Zhao (2012) calculated the compaction subsidence since 1855 under continuous deposition conditions in the modern Yellow River delta: ZK1, ZK2, and ZK10.

Localization groundwater automatic monitors (domestic type) were installed in the three wells, and groundwater dynamic monitoring intervals were set every 1 hour. Figure 2 shows continuous monitoring data of ZK1, ZK2, and ZK10 wells from 17 August 2007 to 09 August 2008. In all cases, groundwater heads underwent several seasonal changes caused by local precipitation, evaporation, oceanic tide, and side permeability of the Yellow River.

The assessment started on 23 February 2008 (an astronomical spring-tide day, 1-2 days after a full moon) and lasted for 358 continuous days. February falls during the dry season in this part of China. According to the measurement of the local meteorological department, the monitoring day was sunny (rainfall was zero). Thus, the influence of groundwater head fluctuation affected by rainfall infiltration was neglected. Average groundwater heads were low on 23 February 2008, with $0.72 \mathrm{~m}$ in ZK1, $1.017 \mathrm{~m}$ in ZK2, and $0.634 \mathrm{~m}$ in ZK10. In order to observe the tidal cycles, a local tide test point $\left(37^{\circ} 55^{\prime} 42.72^{\prime \prime} \mathrm{N}, 119^{\circ} 03^{\prime} 42.99^{\prime \prime} \mathrm{E}\right)$ was set up to the NE of ZK10, and 25 measurements were obtained on 23 February.

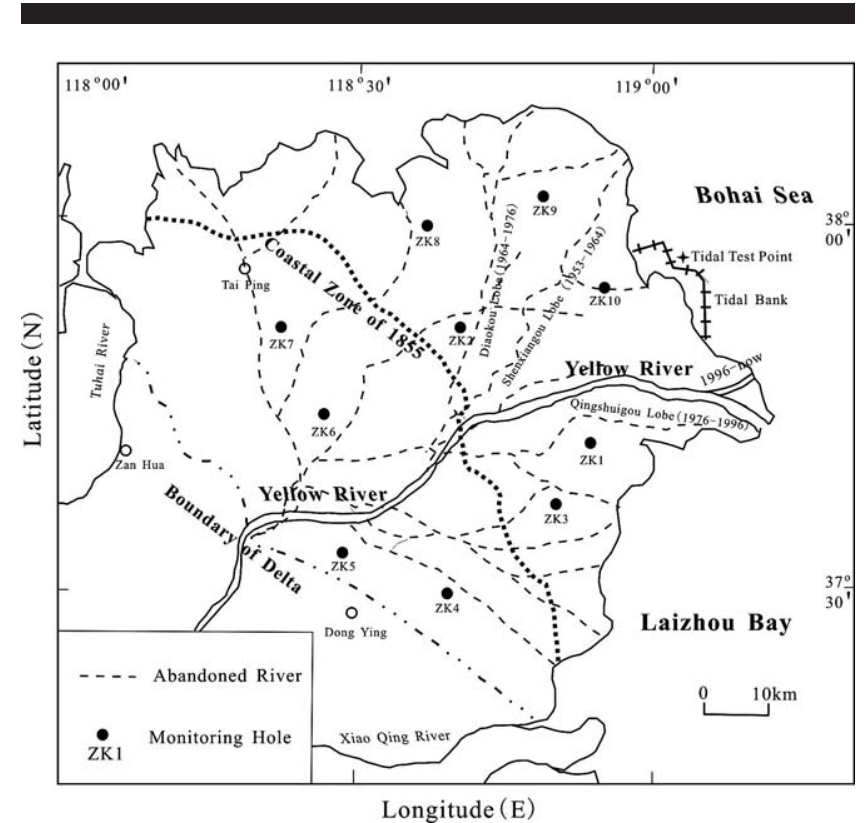

Figure 1. Location of monitoring wells in study area

Based on our observations, the tidal range in the study area was about $120 \mathrm{~cm}$, with a mean of $-31.2 \mathrm{~cm}$. High tide occurred at 0900 with a tidal height of $23 \mathrm{~cm}$, and low tide occurred at 2200 with a tidal height of $-97 \mathrm{~cm}$. Table 1 shows the correlation of monitoring data between shallow groundwater head and oceanic tide height.

The daily distribution curve of the shallow groundwater head in ZK10 and oceanic tide heights is shown in Figure 3. In well ZK10, the amplitude of the groundwater was about $1 / 13$ of oceanic tide level, and the peak groundwater head lagged 3 hours behind the tidal wave. Positive correlation was shown between the groundwater head and oceanic tide in ZK10 (Figure 4). The correlation coefficient of groundwater heads in ZK1 and oceanic tide heights is 0.57 (Figure 5), while the corresponding value in ZK2 was only 0.38 (Figure 6).

The correlation coefficient in ZK10 was 0.85 between groundwater head and tide level, 0.949 during high tide, and 0.62 during low tide. According to this result, periodic groundwater changes are mainly connected to the ebb tide. The distributary lobe of the modern Yellow River delta was 15 $\mathrm{m}$ thick before it was abandoned, and the compaction process was basically terminated in the past 30 years (Gao, Yuan, and Zhao, 2012). No direct hydraulic connection was observed between shallow groundwater and ocean tide in the coast. However, ocean discharge and recharge occurred in the clay silt coast, and the resulting sedimentary stress effect would deliver seawater into the permeable silt aquifer. This submarine groundwater exchange process may cause the shallow groundwater head to rise or fall periodically at a certain period. Moreover, oceanic tide and tide-induced shallow groundwater have complicated periodical and trend patterns.

As a result of the joint actions of sedimentary stress and groundwater head pressure, the ocean influenced area is 


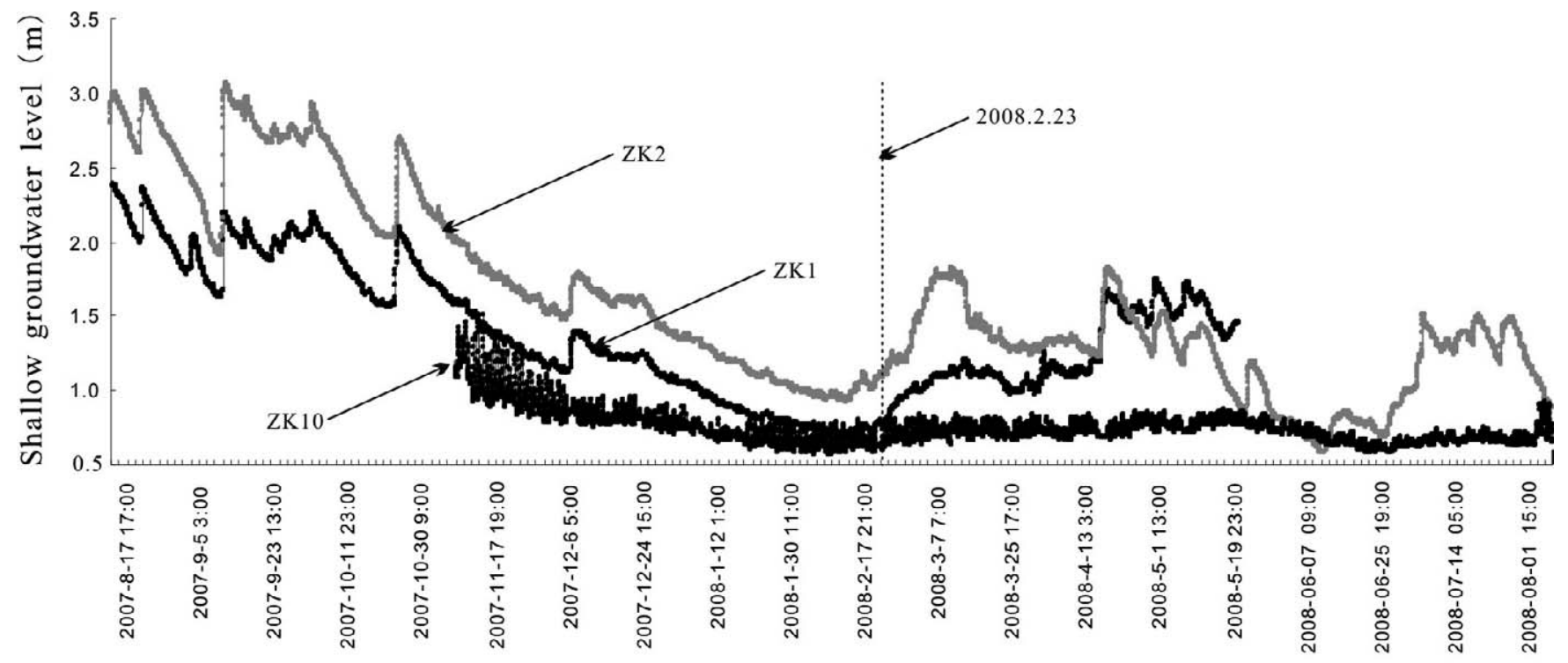

Monitoring time of groundwater in-situ (h)

Figure 2. Curve of groundwater regime in monitoring wells.

about $12 \mathrm{~km}$ to $18 \mathrm{~km}$ landward, based on the evidence of the correlation coefficient between 0.7 and 0.8 . In this area, shallow groundwater seepage flows in silt coastal wetland. Beyond $18 \mathrm{~km}$, oceanic tidal influence is too weak to be observed due to the poor connection in the aquifer, where the seepage flow is controlled by lateral infiltration, precipitation, evaporation, and groundwater exploitation. The movement of wetland shallow groundwater fits the linear seepage law (Darcy, 1856).

\section{WETLAND MODEL}

\section{Cross-Sectional Sketch of Coastal Wetland Model}

According to the change of groundwater head and density, the coastal wetland would be divided into three zones: groundwater seepage zone, tidal-induced transitional zone, and tidal zone. A cross-sectional sketch of the coastal wetland model (Figure 7) was established, which represents several heterogeneity features without involving a very complicated presentation. There is an obvious vegetation zonation along the wetland coast: the reed zone; reed and tamarix chinensis zone; tamarix chinensis and seepweed zone; and seepweed zone. Assuming that pressure of seawater is equal to pressure of wetland groundwater, one can define an interface between seawater and saline groundwater. The underlying mechanisms of the tide-induced groundwater head fluctuation in the three zones are shown in Figure 7. The algorithms could be expressed as in Equation 1.

$$
\rho_{\text {seawater }}\left(H_{1}+H_{2}\right) g=\rho_{\text {groundwater }}\left(h+H_{1}+H_{2}\right) g
$$

where $\rho_{\text {seawater }}$ represents the density of seawater, $\rho_{\text {groundwater }}$ represents the density of groundwater, $h$ represents buried depth of the groundwater in high tidal level, $H_{1}$ represents the changing level of groundwater, $H_{2}$ represents level of the groundwater in low tide, and $g$ represents the acceleration of gravity.

\section{Model Calculation and Debugging}

Through calculation and debugging, the gridding of the study area is divided into $200 \times 200$ cells for $400 \mathrm{~m} \times 500 \mathrm{~m}$. The effective number of elements is 60,834, excluding invalid cells. The simulation started on 10 April 2007. The start flow is shown in Figure 8. Shallow groundwater exhibited slow flow from land to the coastal area, accompanied by scalloped and radial flow. Side seepage of the Yellow River was obviously toward wetland groundwater.

Based on the flow model, flow data were converted into a modular 3D multispecies transport model (MT3DMS) as

Table 1. Correlativity between shallow groundwater and oceanic tide.

\begin{tabular}{|c|c|c|c|c|c|c|c|}
\hline \multirow[b]{2}{*}{ Monitoring Site } & \multirow[b]{2}{*}{ Distance $(\mathrm{km})$} & \multicolumn{2}{|c|}{ High Water Level } & \multicolumn{2}{|c|}{ Low Water Level } & \multirow[b]{2}{*}{ Amplitude (m) } & \multirow[b]{2}{*}{ Correlativity } \\
\hline & & Time of Day & Water Level (m) & Time of Day & Water Level (m) & & \\
\hline Tide test point & 0 & 0900 & 0.23 & 2200 & -0.97 & 1.2 & 1 \\
\hline ZK1 & 28 & 0100-0200 & 0.74 & $1100-1300$ & 0.71 & 0.03 & 0.57 \\
\hline ZK2 & 32 & 0000 & 1.04 & $0900-1200$ & 1.0 & 0.04 & 0.38 \\
\hline ZK10 & 7.0 & 1200 & 0.69 & $0000-0100$ & 0.6 & 0.09 & 0.85 \\
\hline
\end{tabular}


ZK10

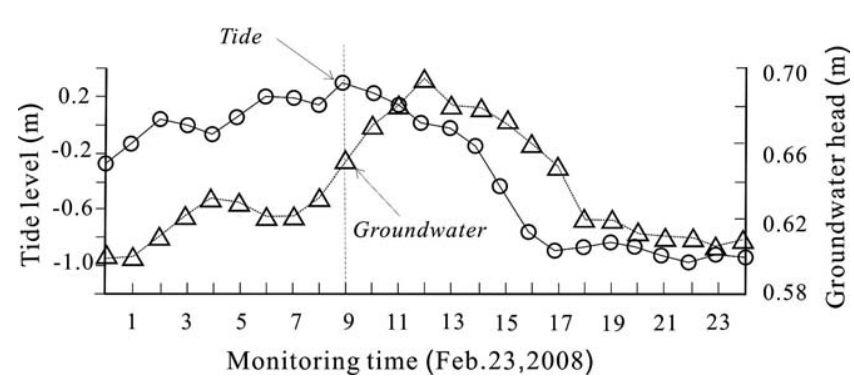

Figure 3. Curve of tide and groundwater in ZK10.

water quality parameters. Chlorine and dispersion degree were considered to be the main parameters in the water quality model. The main reason is that chlorine is one of the most important factors that leads to degrees of salinity. Through calibration and verification, the longitudinal dispersion degree was determined to be $20 \mathrm{~m}$, whereas the transverse dispersion degree value was found to be $2 \mathrm{~m}$. Based on groundwater quality monitoring data from 2007 to 2010 , the model was corrected and the validity of chlorine migration was evaluated. The modeling result (Figure 9) shows that data between calculated and monitoring values of chlorine are matched very well. The uncertainty is smaller than $10 \%$.

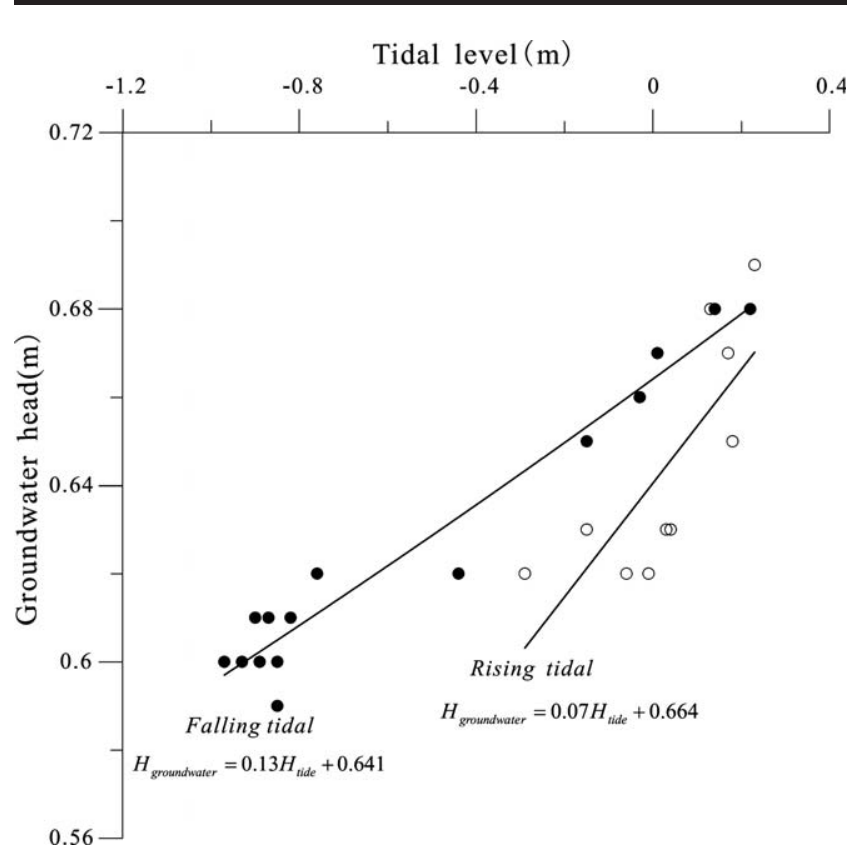

Figure 4. Curve of correlativity between coastal tide and shallow groundwater level in ZK10.

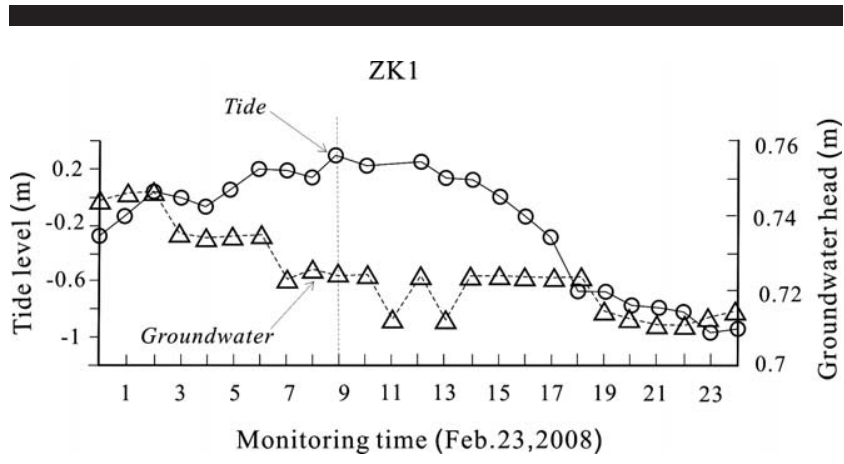

Figure 5. Curve of tide and groundwater in ZK1.

\section{MODEL RESULT}

The changing trend in wetland groundwater for the past 20 years was analyzed by the MT3DMS subroutine package. Under normal conditions, the heads of wetland groundwater were slightly raised (Figure 10), whereas local low-lying areas were flooded. The depth of shallow groundwater ( $1 \mathrm{~m}$ to $3 \mathrm{~m}$ ) resulted in a strong vertical permeability. Precipitation and evaporation led to a $\mathrm{Cl}^{-}$increase, leading to numerous of saltwater distributions.

Several changes were identified in freshwater and saltwater/brine along the distributary channel, crevasse splays, natural levees, floodplains, and sedimentary depressions. The distribution of wetland freshwater is limited. The saline water desalination phenomenon occurs only near the estuarine coastal line. The main driving force is the shallow groundwater and salinity gradients in the coastal wetland, and thus changes the hydrological conditions in the wetland.

\section{Adding Rainfall}

\section{DISCUSSION}

According to local meteorology data, annual precipitation in the Yellow River delta varied from $310.1 \mathrm{~mm}$ to $946 \mathrm{~mm}$. To simulate strong rainfall infiltration effects on wetland water environment, every simulation unit was distributed according to annual maximum precipitation, especially during high flow periods (from July to September every year). Model results show that wetland groundwater rose by an average of $0.3 \mathrm{~m}$,

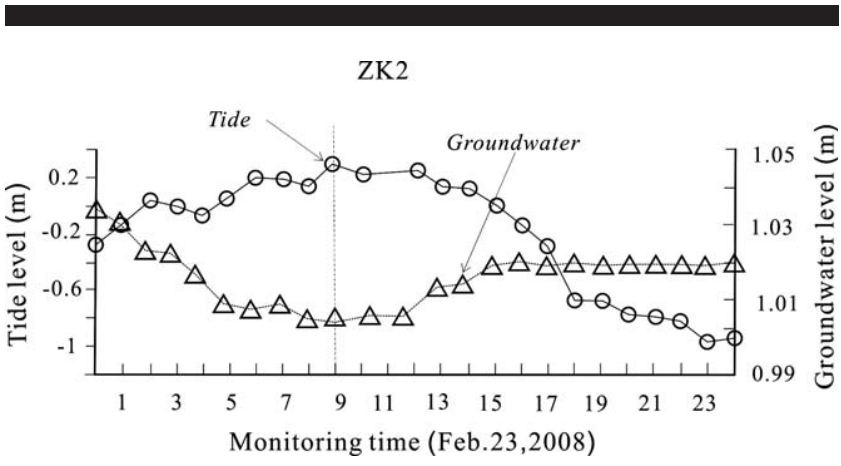

Figure 6. Curve of tide and groundwater in ZK2. 


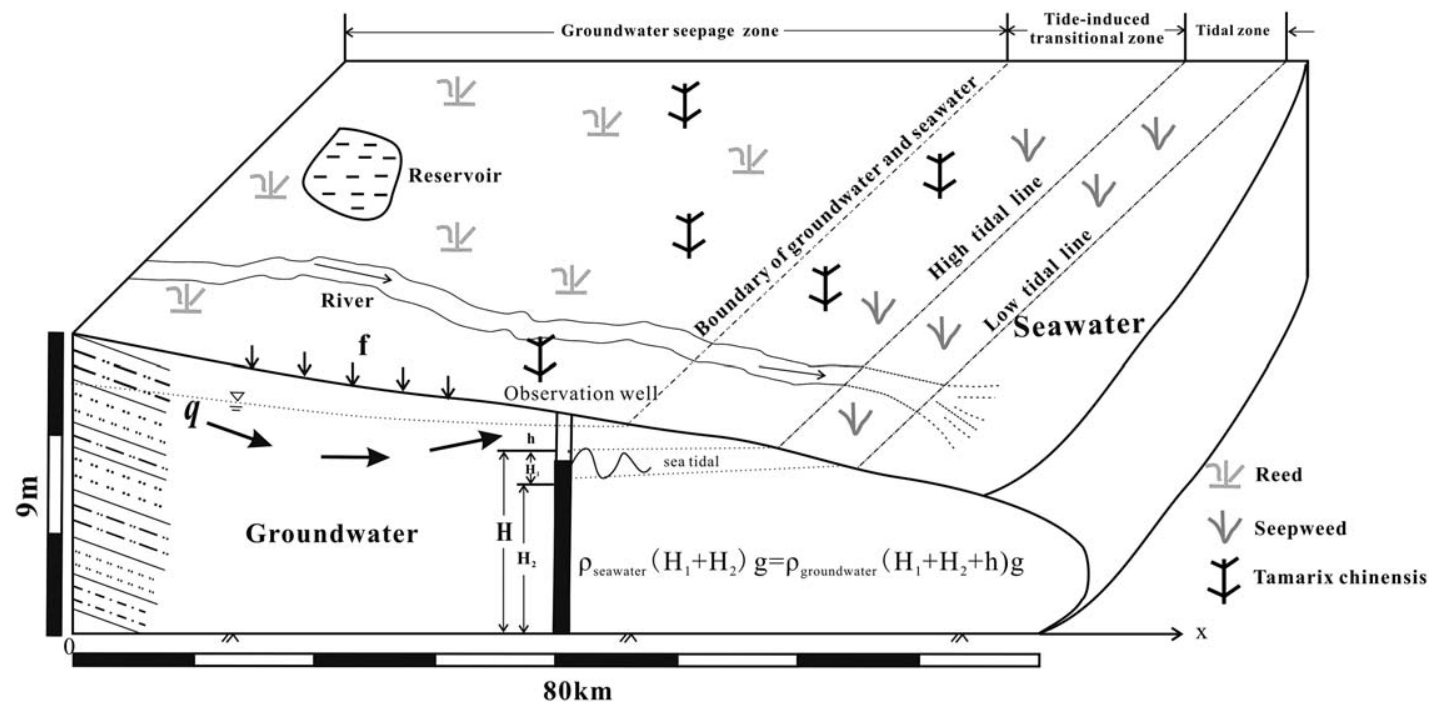

Figure 7. A cross-sectional sketch of coastal wetland model.

together with the following phenomena: groundwater upwelling surface; obvious water recharging in low-lying floodplains or depressions; and significant decrease of $\mathrm{Cl}^{-}$concentration (dropped below $1500 \mathrm{mg} / \mathrm{L}$ in most of the cells). The closer measurements were to inland decline, the more the $\mathrm{Cl}^{-}$was reduced.

\section{River Cutoff}

The cutoff of the lower Yellow River (in the Shandong province) occurred from 1972 to 2001 . The number of cutoff days increased dramatically and reached the longest cutoff

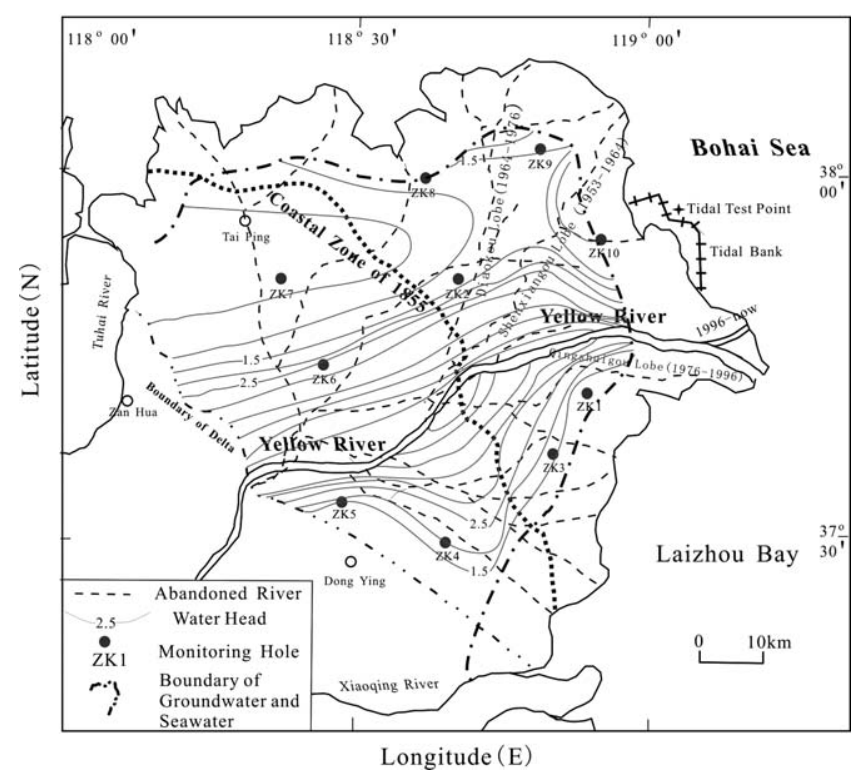

Figure 8. Start groundwater flow in Yellow River delta wetland. record of 226 days in 1997. Remediation was begun in 2002 as a result of the regulation measurements for unified watersediments usage and supply.

Assuming the cutoff time of the Yellow River is 20 days per year, the wetland groundwater head would be modeled to decrease by $10 \mathrm{~cm} / \mathrm{y}$. In contrast, groundwater flow remains basically unchanged because of the effects of low permeability and because there is no unified aquitard in wetland clayey sediments. Assuming the cutoff time of the Yellow River is 200 days per year for three consecutive years, the wetland groundwater head would be decreased by $100 \mathrm{~cm} / \mathrm{y}$. The cutoff of the lower Yellow River directly affects freshwater resources in the wetland. The increasing salinization and decreasing plant coverage caused serious degradation and reduction of the wetland eco-geological system.

\section{Storm Tide}

According to the model, tidal height will be $2.4 \mathrm{~m}$ higher than the normal tidal height during a storm surge. The underground water head will simultaneously increase rapidly. Moreover, storm surges will flood coastal lowland areas because of the low-lying wetland, and the salinity of shallow groundwater within the $2 \mathrm{~km}$ to $12 \mathrm{~km}$ region from the coastline will obviously increase. Such phenomenon can be attributed to the construction of coastal dams, which weaken coastal erosion of seawater.

\section{CONCLUSIONS}

Shallow groundwater heads are obviously affected by oceanic tide in the Yellow River delta wetland along the coastal zone. Ranges of the wetland zone must be readily assessed by measuring fluctuation amplitudes or lags. The influence radius is approximately $12 \mathrm{~km}$ to $18 \mathrm{~km}$ (when the correlation coefficient is 0.7 to 0.8 ) under joint actions of oceanic tide and shallow groundwater seepage flow in the clayey silt coastal wetland. 
(a) ZK1

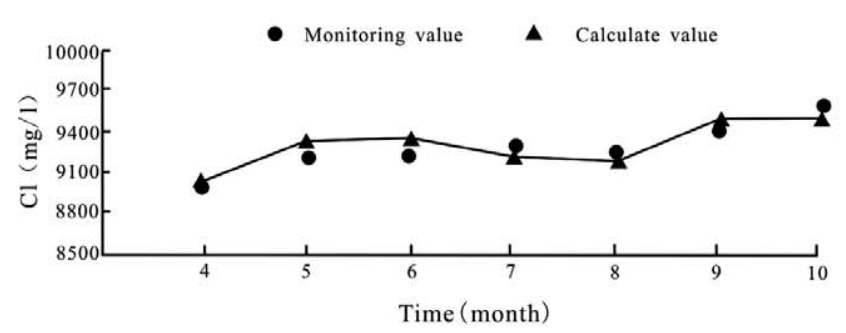

(c) ZK3

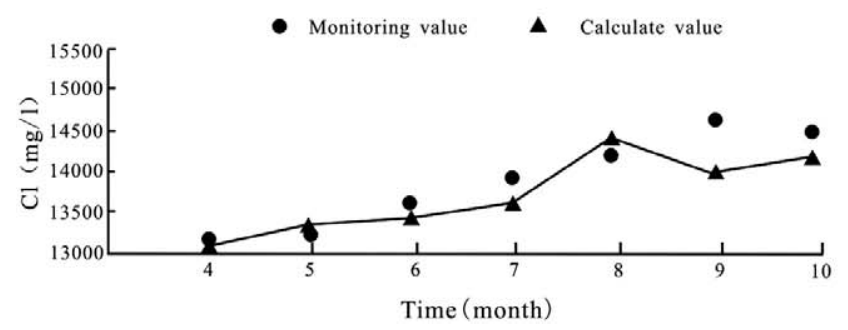

(b) ZK2

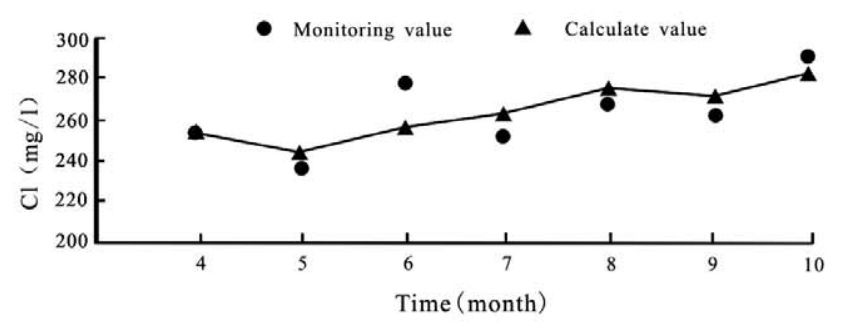

(d) ZK10

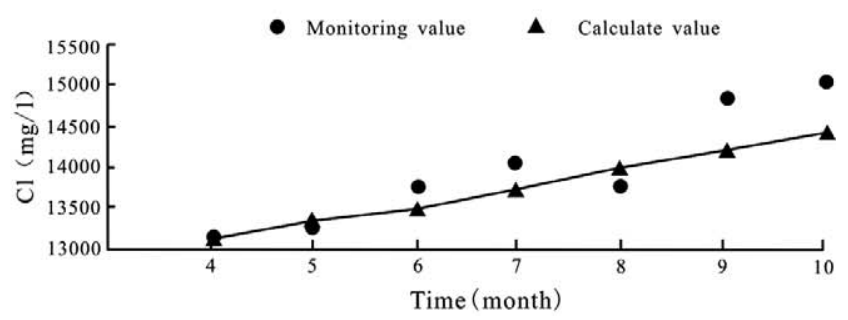

Figure 9. Contrastive curve of simulated value and observed data of chlorine in ZK1, 2, 3, and 10.

The coastal wetland consists of three zones (groundwater seepage zone, tidal-induced transitional zone, and tidal zone) with distinctly different hydraulic properties for a limited width in coastal zone and an infinite width in wetland.

A cross-sectional sketch of the coastal wetland model is constructed by zones of local vegetation (the reed, reed and

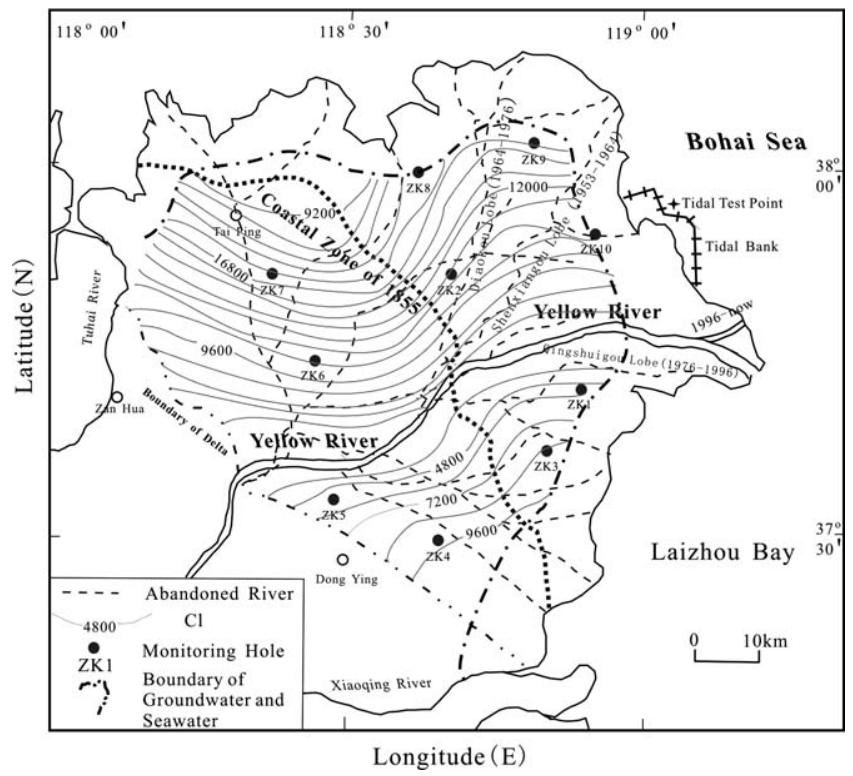

Figure 10. Isoline of chlorine in normal condition. tamarix chinensis, tamarix chinensis and seepweed, and seepweed), shallow groundwater head and quality, seawater (tide and density), and river flow, which are the controlled factors for coastal wetland eco-hydrologic environment. Next, the model will be modified and verified by the conductive effect of sedimentary stratum stress. Moreover, it can be considered by other factors such as oceanic storm, wave, and submarine groundwater discharge.

The coastal wetland is very young, and its evolution time is short. It possesses natural intrinsic vulnerability that controls occurrence, development, and succession by external ecological and environmental factors (delta abandoned lobes in erosion and compactional subsidence, wetland water storage condition, surface clayey silt sediment). As one of the most disturbed regions, coastal wetlands are vulnerable aquifer systems of physical/chemical equilibrium. The application of coastal zone modeling is urgently necessary for the coastal wetland ecohydrologic environment.

\section{ACKNOWLEDGMENTS}

This study was partially supported by the National Basic Research Program (Grants No. 1212010611402 and No. GZH201200505). We thank Prof. Siyuan Ye, Jian Liu, Chunting Xue, Qixiang He, and Dr. Bochao Xu for their help in preparing this manuscript and in collecting field data and/ or conducting geological surveys.

\section{LITERATURE CITED}

Cao, J.F.; Wang, K.J., and Jiang, J.Y., 2007. Impact of lower Yellow River flow cutoff on the formation and exploitation of groundwater in along. Journal of Jilin University (Natural Sciences), 37(5), 937942 [in Chinese]. 
Darcy, H., 1856. Les Fontaines Publiques de la Ville de Dijon. Paris: Dalmon, pp. 590-594.

Cevza, M.K.; Miguel, A., and Medina, J., 2008. The effect of surface/ ground water interactions on wetland sites with different characteristics. Desalination, 226, 298-305.

Cheng, G.D., 1991. Sedimentation and pattern of the Yellow River Delta. Beijing, China: Geological Publishing House, pp. 77-92 [in Chinese].

Feseker, T., 2007. Numerical studies on saltwater intrusion in a coastal aquifer in northwestern Germany, Journal of Hydrogeology, 15, 267-279.

Gao, M.S. and Swarzenski, C.M., 2011. Coastal wetland monitoring in Mississippi River delta. Marine Geology Frontiers, 27(2), 56-60 [in Chinese].

Gao, M.S.; Yuan, H.M., and Zhao, G.M., 2012. Records of compaction subsidence of argillaceous sediments in the modern Yellow River delta. Marine Georesources and Geotechnology, 30(2), 157-166.

Jacob, C.E., 1950. Flow of groundwater. In: Rouse, H. (ed.), Engineering Hydraulics. New York: Wiley, pp. 321-386.

Jiao, J.J. and Tang, Z.H., 1999. An analytical solution of groundwater response to tidal fluctuation in a leaky confined aquifer. Water Resources Research, 35(3), 747-751.

Li, H.L.; Jiao, J.J.; Luk, M., and Cheung, K.Y., 2002. Tideinduced groundwater head fluctuation in coastal aquifers bounded by L-shaped coastlines. Water Resources Research, 38(3), 1024-2002.

Li, H.L.; Li, G.Y.; Chen, J.M., and Boufadel, M.C., 2007. Tide-induced head fluctuations in a confined aquifer with sediment covering its outlet at the sea floor. Water Resources Research, 43(3). doi: 10. 1029/2005WR004724

Nielsen, P.; Fenton, J.D.; Aseervatham, R.A., and Perrochet, P., 1997. Water table waves in aquifers of intermediate depths. Advances in Water Resources, 20(1), 37-43.
Oude Essink, G.H.P., 2001. Salt water intrusion in a threedimensional groundwater system in the Netherlands: A numerical study. Transport in Porous Media, 43(1), 137-158.

Pang, J.Z.; Jing, M.X., and Li, F.L., 2000. Changes and development trend of runoff, sediment discharge and coastline of the Yellow River estuary. Transactions of Oceanology and Limnology, (4), 1-6 [in Chinese].

Restrepo, J.I.; Montoya, A.M., and Obevsekera, J., 1998. A wetland simulation module for the MODFLOW groundwater model. Ground Water, 36(5), 764-770.

Sun, H., 1997. A two-dimensional analytical solution of groundwater response to tidal loading in an estuary. Water Resources Research 33(6), 1429-1435.

Swarzenski, C.M.; Doyle, T.W.; Fry, B., and Hargis, T.G., 2008 Biogeochemical response of organic-rich freshwater marshes in the Louisiana Delta plain to chronic river water influx. Biogeochemistry, 90(1), 49-63.

Townley, L.R., 1995. The response of aquifers to periodic forcing. Advances in Water Resources, 18, 125-146.

Trefry, M.G., 1999. Periodic forcing in composite aquifers. Advances in Water Resources, 22(6), 645-656.

Trefry, M.G. and Bekele, E., 2004. Structural characterization of an island aquifer via tidal methods. Water Resources Research, 40 W01505. doi: 10.1029/2003WR002003.

Wang, Y. and Zhang, Y.Z., 1998. Human activities, break-off water discharge of the Yellow River and their impacts on coastal environment. Journal of Nanjing University (Natural Sciences) 4(3), 257-271 [in Chinese].

Winter, T.C.; Harvey, J.W.; Franke, O.L., and Alley, W.M., 1998. Ground water and surface water a single resource. US Geological Survey Circular, 1139-1145.

Xue, C.T., 1994. Division and recognition of the modern Yellow River delta lobe. Geographical Research, 13(2), 59-66 [in Chinese]. 